DOI:10.17951/h.2017.51.3.49

\begin{tabular}{lcc}
\hline \multicolumn{3}{c}{ A N N A L E S } \\
UNIVERSITATIS MARIAE CURIE-SKLODOWSKA \\
LUBLIN - POLONIA \\
VOL. LI, 3 & SECTIOH H \\
\hline
\end{tabular}

Maria Curie-Skłodowska University in Lublin, Department of Quality and Knowledge Management

KAROLINA JASIŃSKA

karolina_jasinska@interia.pl

\title{
Long-Term Unemployment as a Problem of the Polish Labour Market
}

Bezrobocie długotrwałe jako problem polskiego rynku pracy

Keywords: economics; labour market; labour law; long-term unemployment; human capital Słowa kluczowe: ekonomia; rynek pracy; prawo pracy; długotrwałe bezrobocie; kapitał ludzki

JEL code: E24; J64

\section{Introduction}

Undoubtedly, the high unemployment rate constitutes a problem for many economic markets. In 2012, the unemployment rate in Poland was at the level of 13.4\%, while in 2015, it decreased to $9.7 \%$. Analysing the registered unemployment rate as the only factor, it can be assumed that changes on the Polish labour market are heading in a good direction. However, a thorough analysis of the labour market and taking into account the long-term unemployment rate allow for making conclusions that despite the decrease of the registered unemployment rate, the long-term unemployment is still a problematic issue of the Polish labour market.

According to the Act on promotion of employment and labour market institutions, a long-term unemployed is a person entered into the register kept by the Poviat Labour Office for a total period of more than 12 months within the last 2 years, excluding periods of internships and vocational trainings for adults. A long-term unemployed is considered a person being in a special situation on the labour market. It means 
that such people are privileged when it comes to assigning them to special schemes [Journal of Laws 2004, No. 99 item 1001]. Apart from the statutory definition, there is also another one that describes a long-term unemployed as a person who is out of work for more than 12 months from the date of registration in the Labour Office [Dolny 2014, p. 9]. Thus, in the analysis of statistical data, it should be determined which definition has been adopted in the process of their gathering.

The article aims to illustrate the development of long-term unemployment in Poland. The research problem is based on the question if the issue of long-term unemployment is equally severe for all regions of Poland. The research results will answer the question whether the problem of the long-term unemployment is a problem of the whole country or only some of its regions and, therefore, what kind of action - at central or regional level - should be primarily used to deal with this phenomenon. The data used in the analysis come from GUS (Central Statistical Office), that is the Polish institution gathering statistical data.

\section{Causes, consequences and ways of combating unemployment}

The factors which trigger unemployment, including long-term unemployment, may be divided into economic, demographic as well as social and legal causes. Economic factors encompass the following [Śmilgin 2006, p. 428]:

- impact of fiscal and financial policies;

- increase of international competitiveness;

- low degree of flexibility of the labour market;

- slowdown in economic growth;

- the trade deficit;

- increase of work effectiveness;

- mismatch of supply and demand for work in terms of quantity and structure;

- improper allocation of capital and labour resources;

- liquidation of enterprises and job losses;

- decrease in purchasing power of the society.

The demographic factor that influences the number of unemployed is, above all, the population boom which causes increase of a labour force. As the social and legal factors, the following may be considered [Śmilgin 2006, p. 429]:

- ineffectiveness of vocational development schemes;

- ineffectiveness of schemes implemented by Labour Offices;

- consequences of legal protection of the unemployed;

- legislative changes resulting in a more liberal attitude towards people without work;

- low degree of activeness of the unemployed when applying for a job.

The consequences of unemployment may be distinguished as individual, and related to a family or a society. Among individual consequences of being out of 
work, especially in relation to long-term unemployment, one can place [Śmilgin 2006, pp. 429-430]:

- decline in living standard which may lead to poverty;

- problems with free time management;

- conviction of lower social status;

- limited participation in social, cultural and political life;

- depression-related consequences - sadness, depression, discouragement, indifference;

- risk of mental problems;

- emotional consequences - low level of happiness, satisfaction, feeling of helplessness and hopelessness;

- cognitive deficiencies - problems with focusing, finding oneself in real life situations.

Nonetheless, unemployment is not only a problem of those who are out of work, but it often affects their families. Psychological studies indicate that in families in which at least a father is unemployed, there is an atmosphere of tension and stress. Children coming from such families are not successful at school, and families often abandon their plans, dreams, and cultural life when facing such a situation.

Unemployment can be also considered in social aspects which include [Śmilgin 2006, p. 431]:

- costs related to payment of social benefits;

- increase of taxes and social insurance contributions;

- non-exploited labour resources;

- fear of losing a job among employed people;

- flourishing of social pathologies;

- antisocial behaviour;

- moral corruption of other people;

- delinquency.

The economic and social costs of unemployment can be also divided into direct and indirect costs. Direct costs include real costs, such as expenditures on the accumulation of human capital, which was unused in GDP production, and benefits paid to the unemployed. Direct costs also include the costs of lost profits (tax revenue of the State Treasury). Indirect costs, that are difficult to quantify, include severe social consequences in the form of personality disorders, social pathologies and low birth rates [Kwiatkowski and Liberda 2015, pp. 40-41].

Finding a job is not an easy task for a long-term unemployed person. Such a situation requires some support activities provided by the state. In terms of unemployment, the labour market policy may implement both active and passive measures. Among active means of assisting the unemployed, there can be distinguished job matching, professional trainings, subsidisation of wages and employment-related costs, loans and offering public works. Passive measures taken in order to support people without work include monetary support like, for example, unemployment 
benefits. The objective of the active policy of the labour market is to make the unemployed economically active which may result in finding a job, while the passive policy rather aims at mitigating consequences of being out of work. The latter often meets with criticism since it is said to cause a situation in which the unemployed get accustomed to privileges related to such a status and are unwilling to take up a job, because this would limit their access to certain benefits [Olak 2014, p. 146].

\section{The results}

Assessment of the situation of long-term unemployed on the labour market should take into consideration three indicators [Węgrzyn 2006, p. 229]:

- the unemployment rate, that is the share of unemployed persons in the economically active population;

- the long-term unemployment rate, that is the share of the labour force that is unemployed for more than 12 months;

- the share of long-term unemployment in the total employment.

The data on the long-term unemployed refer to such people who are jobless according to the definition mentioned in the introduction and provided in the Act on promotion of employment and labour market institutions.

Chart 1 presents the registered unemployment rate and the long-term unemployment rate in Poland in the years 2009-2015 and their linear trends within these periods. In 2009 , the registered unemployment rate was at the level of $12.1 \%$ and was growing until 2013 to the level of $13.4 \%$. In 2014 and 2015, the registered unemployment rate was declining to fall below $10 \%$ in 2015 , that is to the level of $9.7 \%$. The linear indicator reflecting the tendency of the registered unemployment rate shows that in years to come it is possible that such a decrease will be continued. Additionally, Chart 1 also illustrates the long-term unemployment rate. In 2009, it amounted to $4.9 \%$ and was increasing to reach 7.8\% in 2012. In 2013, 2014 and 2015, the long-term unemployment rate showed a decreasing trend, and in 2015, it fell to 5.5\%. However, the linear trend of the registered unemployment rate gives no grounds for assuming that it will remarkably decline in the next years, just the opposite - it may still grow.

The interpretation of the long-term unemployment shares in the number of the registered unemployment should be carried out with caution. In Poland, in 2009 compared to 2008 , the number of the long-term unemployed people increased, but their share among all the unemployed decreased. The same trend was observed in most EU countries. It was a result of the large scale of the influx of new people into unemployment caused by the economic crisis [Lewandowski and Magda 2013, p. 91].

Chart 2 depicts the share of the long-term unemployment rate in the registered unemployment. In 2009, the share of the long-term unemployment rate in the registered unemployment amounted to $40 \%$. In subsequent years, this indicator was increasing (except for the years 2013 and 2015), and in 2015, it reached the level of 


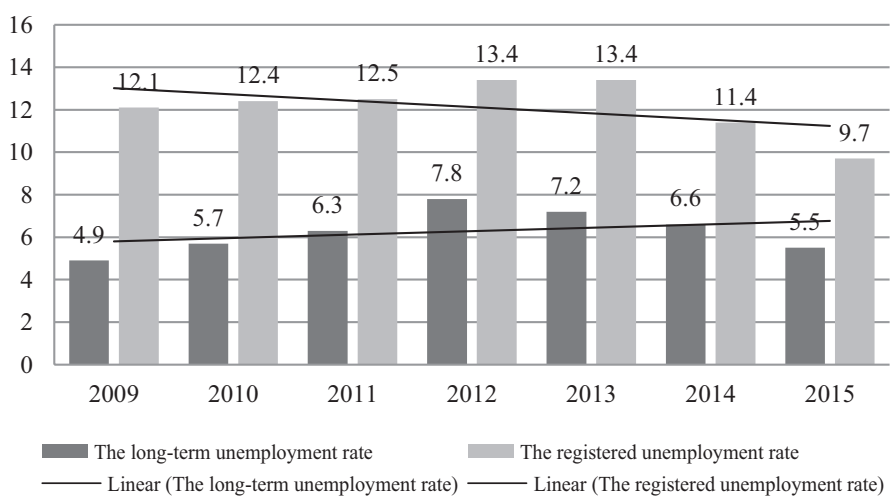

Chart 1. The registered unemployment rate and the long-term unemployment rate as well as their linear trends

Source: Author's own elaboration based on Roczniki Statystyczne Województw (Statistical Yearbooks of the Regions) 2010-2016 provided by GUS.

$57 \%$. It means that despite the situation on the labour market, measured by the registered unemployment rate, improved, the problem of long-term unemployment was unceasingly escalating. It may become evident that the measures used on the labour market aiming at further decrease of the registered unemployment may be scarce due to the fact that the registered unemployment is heavily strained by long-term unemployment. In such a case it seems reasonable to address vocational stimulation programmes to the long-term unemployed. It may also become necessary to carry out an in-depth study of factors causing unemployment that are unique for the given group of people who are out of work, and take actions whose objective would be to prevent the increase of the share in long-term unemployment in the total unemployment. Moreover, it may also appear adequate to incorporate different solutions from those already adopted and applied on the Polish labour market.

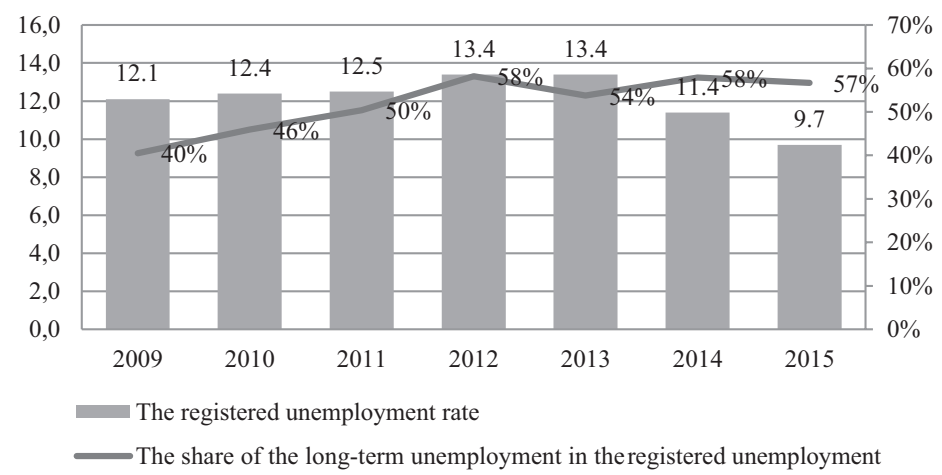

Chart 2. The registered unemployment rate and the share of long-term unemployment in the registered unemployment

Source: Author's own elaboration based on Roczniki Statystyczne Województw (Statistical Yearbooks of the Regions) 2010-2016 provided by GUS. 
Map 1 illustrates long-term unemployment and its share in the registered unemployment in particular regions of Poland in 2015. The long-term unemployment rate in Poland was 5.5\% and its share in the registered unemployment rate was $57 \%$. The range of the long-term unemployment rates was significant since it amounted to $3.0 \%$ in the Wielkopolskie region and 9.2\% in the Warmińsko-Mazurskie region. Similarly, the share of long-term unemployment differed widely across the regions. The lowest share was noted in the Wielkopolskie region - 49\%, and the highest in the Lubelskie and the Podkarpackie regions, where it amounted to $61 \%$. It can be concluded that the measures aiming at economic stimulation of the long-term unemployed should be developed not only on the central level, but also with reference to the local needs. It is especially desired in places where the share of long-term unemployment in the registered unemblovment is significant.

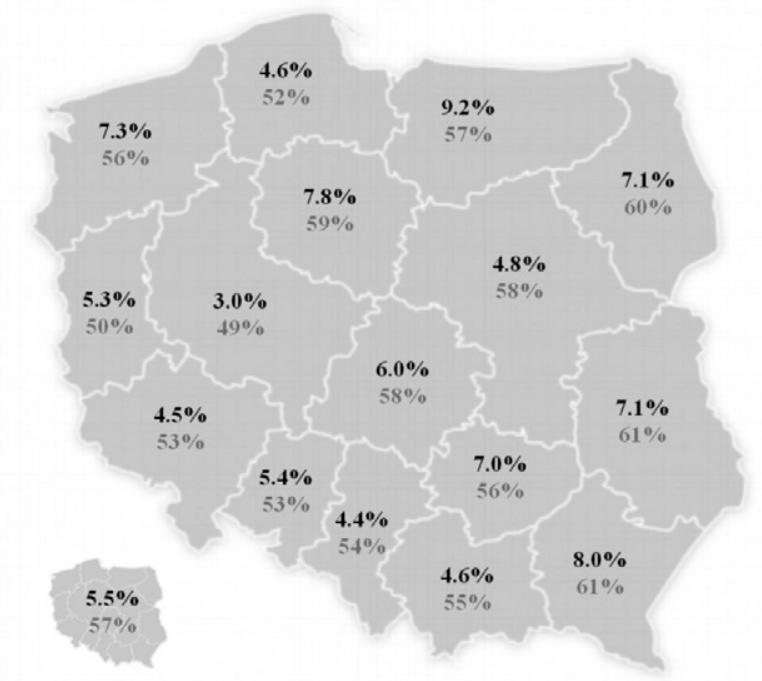

Map 1. Comparison of the long-term unemployment rate and the share of long-term unemployment in the registered unemployment in Poland by regions in 2015

Source: Author's own elaboration based on Rocznik Statystyczny Województw (Statistical Yearbook of the Regions) 2016 provided by GUS.

Interpretation of data on the diagram, defining the long-term unemployment rate and its share in the registered unemployment, indicates the intensity of longterm unemployment in different regions of Poland. The second indicator that may show the intensification of this occurrence may be differentiation between the share of people who are unemployed between 12 and 24 months and those who remain unemployed for more than 24 months.

Map 2 shows diversification of duration of long-term unemployment in different regions of Poland in 2015. Dark gray colour means long-term unemployment (from 12 to 24 months), while light gray colour indicates long-term unemployment (over 
24 months). Taking into account the whole area of Poland, long-term unemployment is primarily unemployment which lasts more than 24 months. $61 \%$ of the long-term unemployed are unemployed for more than 24 months. The lowest share of the long-term unemployed persons over 24 months was noted in the Lubuskie region where it amounted to 55\%. In turn, the largest share of the long-term unemployed persons was noted in the Lubelskie and the Podkarpackie regions where it amounted to $65 \%$. It means that the difference between regions with the highest and the lowest share of the long-term unemployed was significant, because it was amounted to 10 percentage points.

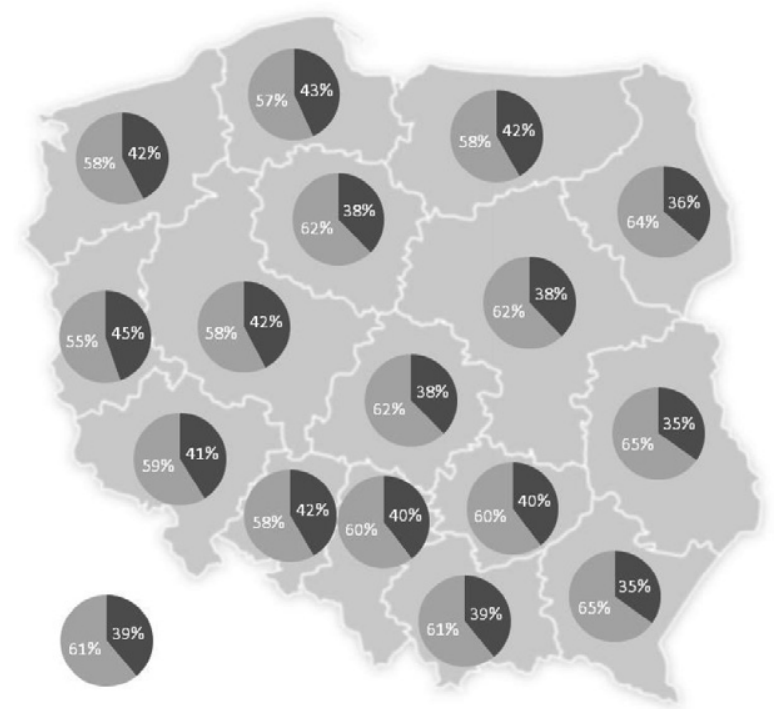

Map 2. Diversification of duration of long-term unemployment in Poland by regions in 2015

Source: Author's own elaboration based on Rocznik Statystyczny Województw (Statistical Yearbook of the Regions) 2016 provided by GUS.

While analysing the subject matter of this study, it is important to provide the demographic structure of the long-term unemployed persons. The structure is developed by the Ministry of Labour and Social Policy (MPiPS). In 2015, the demographic structure of the unemployed for more than 12 months indicated that people who are at the highest level of risk of being out of work are [MPiPS Report]:

- women (54.8\% among the total of the long-term unemployed);

- people between 25-34 years old (25.5\%);

- people graduating from secondary school or lower degree (31.5\%);

- people without any vocational training $(16.2 \%)$.

The provided characteristic indicates the groups of people to whom the activities targeting at reappearance on the labour market should be especially addressed. 


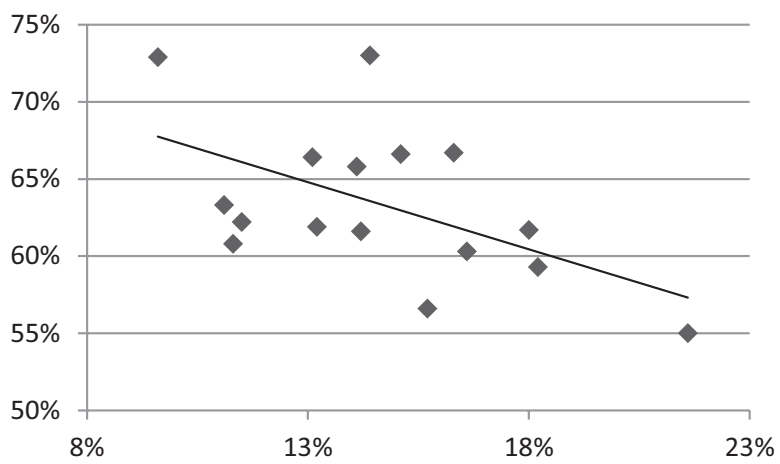

Chart 3. The relationship between the registered unemployment rate and the employment rate after applying active forms of counteracting unemployment in the regions of Poland in 2013

Source: Author's own elaboration based on Rocznik Statystyczny Województw (Statistical Yearbook of the Regions) 2014 provided by GUS and Efektywność działań aktywizujących realizowanych przez powiatowe urzędy pracy w ramach programów na rzecz promocji zatrudnienia, tagodzenia skutków bezrobocia i aktywizacji zawodowej w 2013 roku, p. 8.

The results of the research raise questions about the causes of the differences in the long-term unemployment rate in particular the regions of Poland, as well as the ways of combating them. This means that the problem of the long-term unemployment rate should be covered by further research, especially at regional level. In addition, it is also worth checking to see if the actions undertaken so far, effectively contribute to combating unemployment. Chart 3 provides the relationship between the registered unemployment rate and the employment rate after applying active forms of counteracting unemployment in the regions of Poland in 2013. The analysis shows that the unemployment rate can be linked to the effectiveness of the active form of counteracting unemployment. The linear trend shows that the higher the effectiveness of active anti-unemployment programs, the lower the rate of the unemployment in the region. It may, therefore, seem that one of the possible ways of combating long-term unemployment could be the active form of counteracting unemployment addressed directly to the long-term unemployed. A precondition for the effective fight against long-term unemployment would be high effectiveness of active anti-unemployment programs.

\section{Conclusions}

Summing up, despite the linear trends of the registered unemployment in Poland show that the rate of the total unemployment declines, the linear indicator of long-term unemployment presents its slight increase in the near future. Moreover, the share of long-term unemployment in the registered unemployment is going upwards. This means that although the situation on the labour market is getting better, 
long-term unemployment is becoming a more and more problematic issue. The article goes beyond the usual pattern of analysis of the long-term unemployment rates only for the whole country. The long-term unemployment rate between the regions of Poland is compared. It was indicated that this problem does not apply to all regions of Poland on an equal scale. Both the long-term unemployment rate and the share of the long-term unemployment in the registered unemployment vary between particular regions of Poland. Such variation also concerns the duration of long-term unemployment between those regions. It brings the conclusion that there is a need for implementation of some activities whose objective is to determine the causes of long-term unemployment on a regional scale. Subsequently, some measures stimulating the unemployed to coming back to the labour market should be developed. Finally, these measures should be implemented not only on the central scale but especially on the local one.

\section{Bibliography}

Raport MRPiPS, Bezrobotni pozostajacy bez pracy powyżej 12 miesięcy od momentu zarejestrowania się oraz dtugotrwale bezrobotni w 2015 roku, Ministerstwo Rodziny, Pracy i Polityki Społecznej, Departament Rynku Pracy.

Dolny, E., Rozmiary, struktura i czynniki wptywajace na ryzyko dtugotrwałego bezrobocia w Polsce, [in:] A. Bronk, Z. Wiśniewski, M. Wojdyło-Preisner (eds.), Ryzyko dtugotrwałego bezrobocia w Polsce. Diagnoza i metody zapobiegania, Ministerstwo Pracy i Polityki Społecznej: Centrum Rozwoju Zasobów Ludzkich, Warszawa 2014.

Efektywność działań aktywizujących realizowanych przez powiatowe urzędy pracy w ramach programów na rzecz promocji zatrudnienia, łagodzenia skutków bezrobocia i aktywizacji zawodowej w 2013 roku, MPiPS, Warszawa 2014.

Kwiatkowski, E., Liberda, B., Determinanty rozwoju Polski. Rynek pracy i demografia, Polskie Towarzystwo Ekonomiczne, Warszawa 2015.

Lewandowski, P., Magda, I., Rynek pracy okresie wyjścia z kryzysu, Centrum Rozwoju Zasobów Ludzkich, Warszawa 2013.

Olak, A., Zjawisko bezrobocia a zagrożenie społeczne, "Modern Management Review”, vol. 19, no. 21 (4), Oficyna Wydawnicza Politechniki Rzeszowskiej, Rzeszów 2014.

Rocznik Statystyczny Województw 2010, GUS.

Rocznik Statystyczny Województw 2011, GUS.

Rocznik Statystyczny Województw 2012, GUS.

Rocznik Statystyczny Województw 2013, GUS.

Rocznik Statystyczny Województw 2014, GUS.

Rocznik Statystyczny Województw 2015, GUS.

Rocznik Statystyczny Województw 2016, GUS.

Śmilgin, M., Indywidualne i społeczne skutki bezrobocia na tle globalizacji w: Nierówności Społeczne a Wzrost Gospodarczy, no. 8, Rzeszów: Uniwersytet Rzeszowski. Katedra Teorii Ekonomii, Rzeszów 2006.

Ustawa z dnia 20 kwietnia 2004 r. o promocji zatrudnienia i instytucjach rynku pracy (Journal of Laws 2004 No. 99 poz. 1001).

Węgrzyn, G., Bezrobotni dtugotrwale - problem XXI wieku, [in:] D. Kopycińska (ed.), Regulacyjna rola państwa we współczesnej gospodarce, Katedra Mikroekonomii, Uniwersytet Szczeciński, Szczecin 2006. 


\section{Long-Term Unemployment as a Problem of the Polish Labour Market}

The objective of this study is to analyse the issue of the long-term unemployment and the ways it changes on the Polish labour market. The research problem is based on the answer to the question if the issue of long-term unemployment is equally severe for all regions of Poland. The research results will answer the question whether the issue of long-term unemployment is a problem of the whole country or only some of its regions and, therefore, what kind of action - at central or regional level - should be primarily used to deal with this phenomenon. The data used in the analysis come from GUS (Central Statistical Office), that is the Polish institution gathering statistical data.

\section{Bezrobocie długotrwałe jako problem polskiego rynku pracy}

Celem opracowania jest analiza bezrobocia długotrwałego oraz sposobu jego zmian na polskim rynku pracy. Problem badawczy opiera się na odpowiedzi na pytanie, czy sprawa bezrobocia długookresowego jest $\mathrm{w}$ równej mierze dotkliwa dla wszystkich regionów Polski. Wyniki badań pozwolą odpowiedzieć na pytanie, czy problem długotrwałego bezrobocia jest problemem całego kraju czy tylko niektórych jego regionów, a zatem jakie działania - na szczeblu centralnym lub regionalnym - powinny być przede wszystkim wykorzystywane do radzenia sobie z bezrobociem długotrwałym. Dane zaczerpnięte do badań pochodzą z GUS-u, czyli instytucji państwa polskiego zajmującej się zbieraniem danych statystycznych. 